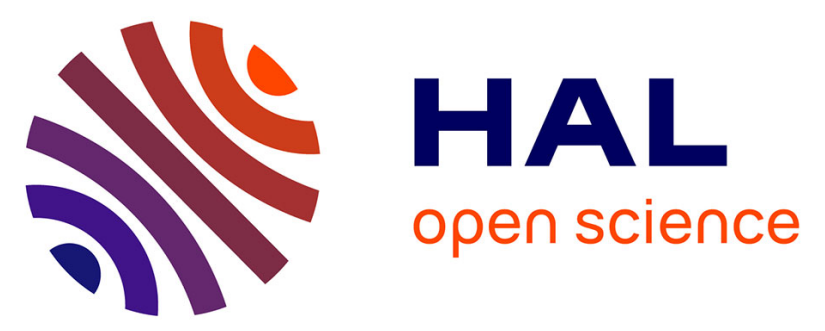

\title{
The beauties and the bugs: A scenario for designing flower strips adapted to aphid management in melon crops
}

Alexandra Schoeny, Antoine Lauvernay, Jérôme Lambion, Christophe Mazzia, Yvan Capowiez

\section{To cite this version:}

Alexandra Schoeny, Antoine Lauvernay, Jérôme Lambion, Christophe Mazzia, Yvan Capowiez. The beauties and the bugs: A scenario for designing flower strips adapted to aphid management in melon crops. Biological Control, 2019, 136 (103986), pp.1-10. 10.1016/j.biocontrol.2019.05.005 . hal02619746

\section{HAL Id: hal-02619746 \\ https://hal.inrae.fr/hal-02619746}

Submitted on 25 May 2020

HAL is a multi-disciplinary open access archive for the deposit and dissemination of scientific research documents, whether they are published or not. The documents may come from teaching and research institutions in France or abroad, or from public or private research centers.
L'archive ouverte pluridisciplinaire HAL, est destinée au dépôt et à la diffusion de documents scientifiques de niveau recherche, publiés ou non, émanant des établissements d'enseignement et de recherche français ou étrangers, des laboratoires publics ou privés.

\section{(ㅇ)(1) $\$$}

Distributed under a Creative Commons Attribution - NonCommercial - NoDerivatives| 4.0 
1 The beauties and the bugs: a scenario for designing flower strips adapted to

2 aphid management in melon crops

3

4 Alexandra Schoeny ${ }^{1 *}$, Antoine Lauvernay ${ }^{1}$, Jérôme Lambion ${ }^{2}$, Christophe Mazzia ${ }^{3}$ and Yvan

5 Capowiez $^{4}$

6

$7 \quad{ }^{1}$ Pathologie Végétale, INRA, 84140, Montfavet, France

$8 \quad{ }^{2}$ Groupe de Recherche en Agriculture Biologique, 84911, Avignon, France

9 3'Université d'Avignon, Aix-Marseille Université, CNRS, IRD, IMBE, 84916 Avignon, France $10 \quad{ }^{4}$ EMMAH, INRA, UAPV, 84914, Avignon, France

11

12 *Corresponding author: alexandra.schoeny@inra.fr

13

14

15 Keywords

16 Conservation biological control, Cucumis melo, ecological engineering, field margins, habitat

17 manipulation, natural enemies 
20 Flower strips appear to be a promising lever for promoting pest control but a careful selection

21 of the plant species used is needed prior to implementation to avoid possible negative side effects. In the case of open field melon crops, the main pitfall would be to generate aphid and aphid-borne virus reservoirs near the crops. Combining biotests under controlled conditions and data from the literature, we assessed 18 candidate plant species, and ruled-out those posing a potential risk of hosting Aphis gossypii (melon pest and virus vector), Myzus persicae (virus vector) and/or viruses (Cucurbit aphid-borne yellows virus (CABYV), Cucumber mosaic virus (CMV), Watermelon mosaic virus (WMV) and Zucchini yellow mosaic virus (ZYMV)). Five plant species made it through the selection process: cornflower, grass pea, sainfoin, salad burnet and sweet marjoram. Flower strips sown with a mix of these five plant species were evaluated in a five-year field experiment. They displayed a flowering continuum likely to provide a food resource to natural enemies throughout the growing season. Their potential to host natural enemies was compared to those of grass strips and bare soil by monitoring generalist and specialist predators within the different field margins and melon crop. Flower margins supported significantly more of these natural enemies than grass margins and bare soil. All predator taxa analyzed responded positively to the floral resources displayed. Spiders were 3.2 times more abundant in pitfall traps placed in flower margins than in bare soil. Generalist predators and aphid specialist predators collected using a vacuum sampler were 5.5 and 9.1 times more abundant in flower margins than in bare soil, respectively. Interception traps set for weekly periods showed that coccinellid and syrphid fluxes were significantly enhanced near 


\section{Introduction}

42

43

Aphids and aphid-borne viruses can cause severe economic damage to open field vegetable crops. In conventional cropping systems, synthetic insecticides are often the first option for controlling aphids. However their efficiency is frequently challenged by the development of resistant clones (Bass et al., 2015) and their usage is increasingly questioned due to environmental and health risks. In addition, they are of little relevance to limit non-persistently transmitted viruses, where acquisition and inoculation occur in a matter of seconds (Perring et al., 1999). Cultural practices such as the use of plastic mulches or row covers may limit both aphid colonization and the transmission of aphid-borne viruses but only provide temporary protection and lead to plastic waste (Lecoq and Desbiez, 2012). Whenever available, resistant cultivars are the easiest, most efficient and environmentally friendly way to manage pests and diseases, but genetic resistance durability can be jeopardized by the emergence of adapted clones. A complementary way of reducing aphid and virus damage within an open field crop can be to take advantage of ecological services provided by the environment. For example, Losey and Vaughan (2006) estimated that the annual value of pest control by wild native insects is $\$ 4.5$ billion in the United States. Unfortunately, agricultural landscapes are rarely optimal environments for natural enemies. The excessive use of insecticides and the lack of alternative food resources generally limit the performance of natural enemies (Tscharntke et al., 2016). Thus increasing attention is being paid to conservation practices that enhance the survival, fecundity, longevity and behavior of natural enemies. In particular, habitat management seeks to alter the habitats within or around crops to improve the availability of the resources required for optimal performance by natural enemies (Gurr et al., 2017; Landis et al., 2000). To achieve pest control it is crucial to provide nectar, pollen, alternative hosts or prey, shelter, to parasitoid 
and predator insects. Although flowering plants provide many of these food resources, habitat manipulation should be more than "chocolate-box ecology" (Gurr et al., 2004). Floral displays of plants picked at random can be at best ineffective, at worst detrimental by favoring pest populations over beneficial organisms. Thus a rigorous evaluation of the candidate insectary plants prior to flower strip implementation is needed to avoid these adverse effects.

Melon, particularly the Charentais-type (Cucumis melo var. cantalupensis), is a very popular fruit in France. It is cultivated between March (early tunnel plantings) and September (late open field plantings) in three main production areas: South-East, South-West and Central-West. Nearly $40 \%$ of the national production is in the South-East (286000 t, 14000 ha in 2017, www.agreste.agriculture.gouv.fr). Open field melon crops are regularly impacted by biotic stresses, among which aphids and aphid-borne viruses. The melon aphid Aphis gossypii Glover (Hemiptera: Aphididae) is the only aphid species colonizing melon crops in France, causing leaf-curling, stunting and even plant death when colonization is intense. Myzus persicae Sulzer (Hemiptera: Aphididae) has not yet been found to colonize melon crops in France, but it is the most important aphid virus vector, able to transmit over 100 plant viruses (Blackman and Eastop 2000). Both aphid species are efficient vectors for four viruses frequently observed on melon crops in France: Cucurbit aphid-borne yellows virus (CABYV, Polerovirus, Luteoviridae), Cucumber mosaic virus (CMV, Cucumovirus, Bromoviridae), Watermelon mosaic virus (WMV, Potyvirus, Potyviridae) and Zucchini yellow mosaic virus (ZYMV, Potyvirus, Potyviridae). WMV and ZYMV are the most harmful viruses, causing mosaic symptoms on leaves, plant stunting and reduced fruit yield, but also, when infection is severe, leaf deformation such as filimorphism, mosaic on fruits, coupled with marbling and hardening of the flesh for ZYMV (Lecoq and Desbiez, 2012).

In France as elsewhere in Europe, increasing importance is being granted to habitat management, not only in organic farming systems, but also in conventional systems due to the 
progressive reduction of pesticide usage imposed by changes in regulation. For melon

91 producers, flower strips could be a promising lever for controlling aphids. Several seed companies sell blends which are supposed to boost biological control services. These advised blends are identical regardless of crop and are not specific for melon crops. Yet pathogen corteges differ a lot depending on the crops, so botanical composition should be crop-specific to avoid negative side effects. In the case of open field melon crops, the main pitfall would be to generate aphid and virus reservoirs near the crop by sowing plant species likely to host melon aphids and viruses.

In this study, we focused on the selection and evaluation of flowering species appropriate for

99 melon crops. The first step was to screen a set of candidate plants under controlled conditions

100 to design a mix that minimizes the risk of hosting aphids (A. gossypii and M. persicae) and

101 viruses (CABYV, CMV, WMV and ZYMV). The second step was to evaluate, under field 102 conditions, the potential of the corresponding flower strips to enhance aphid predator 103 abundance within field margins and melon crop. 


\section{Materials and methods}

105

106 2.1. Plant screening under controlled conditions

107

108

2.1.1. Plant species shortlist and plant rearing

109 Twenty plant species from 13 families were selected for the experiments (Table S1). Melon

110 (Cucumis melo L.) and pepper (Capsicum annuum L.) were used as controls.

111 Virus-free plants were grown in an insect-proof greenhouse without pesticides. Seedlings were

112 prepared in flats containing a peat/coco coir substrate (080 Klasmann-Deilmann France,

113 Bourgoin Jallieu, France) and irrigated daily with bore water. Plantlets were transplanted

114 individually to plastic pots $(9 \mathrm{~cm}$ wide $\times 8 \mathrm{~cm}$ high) containing a peat/clay substrate (404

115 Klasmann-Deilmann France) and irrigated daily with bore water, the $\mathrm{pH}$ of which was adjusted

116 to 5.8. Plants were used at the vegetative stage (3-8 week old depending on plant species, Table

117 S1). During biotests, plants were irrigated daily with a nutrient solution (Soluveg Essentiel 16-

118 5-25, Angibaud \& Spécialités, La Rochelle, France).

119

$120 \quad$ 2.1.2. Aphid rearing

121 Aphids were reared on virus-free plants in growth cabinets equipped with LED tube lights

122 (4000K) under a photoperiod of 16:8 (L:D) h. Aphis gossypii (clone NM1, Thomas et al., 2012)

123 was reared on 3-5 week old melon plants (cv. Védrantais) at $24 / 21 \pm 1^{\circ} \mathrm{C}$ day/night. Myzus

124 persicae (clone Patho) was reared on 5-8 week old pepper plants (cv. Yolo Wonder) at $21 \pm 1^{\circ} \mathrm{C}$

125 day/night. Four weeks before experiments, mass rearing was shifted to synchronous rearing in

126 order to manipulate 7 day-old apterous female cohorts.

127 
129 Each plant species was evaluated for its capacity to host two aphid species: A. gossypii and $M$.

130 persicae. For each aphid species, no-choice settling tests were carried out on 10 plants per plant

131 species, each plant tested constituted a replicate. Ten 7 day-old apterous females were deposited

132 per plant. After $24 \mathrm{~h}$, settled females were counted and removed. The acceptance rate was

133 calculated as the number of recovered females divided by 10. After six additional days, the

134 offspring produced during the initial $24 \mathrm{~h}$ period was counted. The reproductive rate was

135 calculated as the number of offspring divided by the number of recovered females. Together,

136 the acceptance rate and the reproductive rate were used to assess the capacity of the tested aphid

137 species to accept the tested plant species as a suitable host. Results were compared to those

138 obtained on plant species used for aphid rearing, which were considered as reference plant

139 species (melon for A. gossypii, pepper for M. persicae).

141 2.1.4. Plant-virus interaction biotests

142 Each plant species was evaluated for its capacity to host the most frequently observed viruses

143 in melon crops in France: CABYV, CMV, WMV and ZYMV. For CABYV and CMV, one

144 isolate was used; for WMV and ZYMV, two isolates reflecting the recent changes in the genetic

145 structure of these viruses in France were used (Table 2). For each viral isolate, biotests were

146 conducted on eight plants per plant species, each plant tested constituted a replicate. Melon (cv.

147 Védrantais) was used as positive control.

148 The persistently aphid-transmitted CABYV was tested through aphid transmission using $A$.

149 gossypii as vector. Virus sources were infected melon plants (cv. Védrantais). Virus-free aphids

150 reared as in Section 2.1.2. were collected with a fine-tip paint brush and transferred onto virus

151 sources. After a $48 \mathrm{~h}$ acquisition access period (AAP), groups of 10 aphids were gently

152 transferred to virus-free test plants for a $48 \mathrm{~h}$ inoculation access period (IAP). At the end of the 
153 IAP, aphids were killed by spraying the plants with two systemic insecticides $(0.5 \mathrm{ml} / \mathrm{l} \mathrm{NUPRID}$

154 200, Nufarm SAS) at 24h intervals. Plants were then placed in a dedicated greenhouse for 4-5

155 weeks of incubation.

156 The non-persistently aphid-transmitted CMV, WMV and ZYMV were tested through

157 mechanical inoculation. Virus sources were infected zucchini plants (Cucurbita pepo L. cv.

158 Diamant). Inoculum was prepared by grinding $2 \mathrm{~g}$ of young leaf tissue with a mortar and pestle

159 in $8 \mathrm{ml}$ of a solution containing $0.03 \mathrm{M} \mathrm{Na}_{2} \mathrm{HPO}_{4}$ with $0.2 \%$ DIECA. Carborundum $(75 \mathrm{mg} / \mathrm{ml})$

160 and activated charcoal $(75 \mathrm{mg} / \mathrm{ml})$ were added before rub-inoculation of test plants. Plants were

161 rinsed with tap water and placed in a dedicated greenhouse for 3-5 weeks of incubation. Viruses

162 were detected using a double antibody sandwich enzyme-linked immunosorbent assay (DAS-

163 ELISA) with specific polyclonal antisera produced in our laboratory. Plants were considered

164 infected when the absorbance at $405 \mathrm{~nm}$ (Multiskan EX, Thermo Electron Corporation) was

165 three times above the mean value of the healthy controls (Schoeny et al., 2017). The

166 transmission rate was calculated as the number of infected plants to the total number of tested

167 plants.

168

169

2.2. In situ evaluation of field margins

170

171

2.2.1. Experimental design

172 Five field trials were conducted between 2011 and 2015 at the INRA St Paul experimental

173 station in Avignon (southeastern France, $43^{\circ} 54^{\prime} 53 \mathrm{~N}, 4^{\circ} 52^{\prime} 59 \mathrm{E}$ ) on a 1.3 ha plot edged north

174 and south by 6 m-high cypress trees. The experimental design consisted of a melon crop with

175 three modalities of field margin management: bare soil, flower strip and grass strip (Figure S1).

176 Each modality consisted of two strips $25.5 \mathrm{~m}$ apart: one 'north strip' and one 'south strip'. Strips

177 were $55 \mathrm{~m}$ long and $3 \mathrm{~m}$ wide. The spatial organization of the modalities was defined randomly 
each year. Flower strips were sown with a mix of five plant species selected after the above mentioned biotests: sainfoin (Onobrychis viciifolia, $22 \mathrm{~kg} / \mathrm{ha}, 40 \%$ ) grass pea (Lathyrus sativus, $16.5 \mathrm{~kg} / \mathrm{ha}, 30 \%$ ), salad burnet (Sanguisorba minor, $11 \mathrm{~kg} / \mathrm{ha}, 20 \%$ ), cornflower (Centaurea cyanus, $2.75 \mathrm{~kg} / \mathrm{ha}, 5 \%$ ) and sweet marjoram (Origanum majorana, $2.75 \mathrm{~kg} / \mathrm{ha}, 5 \%$ ). The

182 proportions of each plant species in the mix were defined with the expertise of a seed seller.

183 Grass strips were sown with ryegrass (Lolium perenne, $50 \mathrm{~kg} / \mathrm{ha}$ ). Flower and grass strips were

184 sown during the second half of March (18-30 March) approximately two months before melon 185 planting (24-31 May). Special attention was given to soil preparation and weed control to foster the establishment and growth of the field margins. Two tillage operations (disc harrowing before or after ploughing) were implemented in late autumn/winter. Just before sowing, a rotary

188 harrow completed soil preparation to create a perfect seedbed. Flower and grass strips were 189 sown with a portable spreader $(421-\mathrm{S}$, Solo®). For the flower strips, to optimize seed 190 germination and considering the difference in seed size of the five plant species selected, large seeds (sainfoin, grass pea, salad burnet) were sown in a first passage, followed by a comb

192 harrow, the small seeds (cornflower, sweet marjoram) were sown in a second passage, 193 completed by a roller. Flower and grass strips were irrigated with sprinklers (up to $63 \mathrm{~mm}$ per 194 week depending on weather conditions) and hand-weeded when needed. The bare soil modality 195 was maintained using mechanical weeding.

196 Melon crops were set up between the north and south strips after soil preparation with a rotary 197 harrow. Charentais-type melon seedlings at the 1-3 leaf stage were planted in 16 rows (1.5 m 198 row spacing) parallel to the strips on dark brown plastic mulch with drip irrigation (Figure S1).

199 Basal PK fertilization (0-25-25) was applied during winter/early spring (250-300 kg/ha), 200 complemented with ammonium nitrate (33-0-0) during spring in 2011 and 2012 (130 kg/ha). A 201 monoammonium phosphate (12-61-0) fertigation was applied just after planting (100 kg/ha) to 202 boost melon growth. No insecticides were applied during trials. 


\subsubsection{Plant development monitoring}

205 The development of sown strips was monitored 2-3 times before melon planting with the 206 quadrat technique. A $1-\mathrm{m}^{2}$ wooden frame was randomly placed in the north and south strips and 207 the percentage of plant cover was visually estimated.

208 The flowering of flower strips was monitored 4-6 times after melon planting. Ten randomly 209 chosen plants per species were examined in one quadrat per strip in 2011 and 2012, in five 210 quadrats per strip in 2013, 2014 and 2015. Plants were considered at flowering stage when

211 displaying at least one open flower. Specific flowering rates were calculated as the number of 212 flowering plants divided by the number of examined plants.

\subsubsection{Arthropod monitoring}

215 To assess the biocontrol potential of the different field margins, we surveyed both generalist (able to feed on various prey) and specialist (mainly aphidophagous) predators. Three complementary trapping methods were used: pitfall traps to assess epigeal spiders moving on

218 the soil surface, vacuum sampling to assess arthropods active in the vegetation, and interception 219 traps to assess arthropods flying or moving from the margins to the crop (Figure S1).

220 Pitfall trapping was used at two dates in $2013(27 / 06,19 / 07)$ and $2014(23 / 06,23 / 07)$ when the 221 vegetation was fully developed. Traps were placed within each field margin strip (north and 222 south) and within the melon crop at two different positions (inter-rows 3 and 15) and left in 223 place for one week of monitoring. The experimental design comprised two and three replicates 224 per strip or position in 2013 and 2014, respectively. The data of 120 traps were analyzed.

225 Vacuum sampling was used at two dates in $2012(21 / 06,03 / 07), 2013(20 / 06,01 / 07)$ and 2014 $226(20 / 06,10 / 07)$. At each date and for each modality, four samplings were made in the morning 227 in the melon crop (inter-rows 6 and 12) and field margins (for flower and grass strips: two in 
north strips and two in south strips; for bare soil: four in the spontaneous vegetation of the

229 pathway between the north cypress hedge and the trial, to avoid sampling dusty dry soil). For 230 each sample, the pipe of the vacuum device (441, Solo®) equipped with a collection bag was 231 placed $5 \times 1$ s within the canopy.

232 Interception trapping was used in 2014 (13/06-18/07) and 2015 (29/05-10/07). Lightweight tent 233 traps (BT2003, Bugdorm, MegaView Science Co., Taiwan) made of black polyester fabric 234 (96x26 mesh/square inch, mesh aperture: $680 \mu \mathrm{m})$ were used (Figure 1a). They are $60 \mathrm{~cm}$ wide, $23560 \mathrm{~cm}$ long and $60 \mathrm{~cm}$ high, with a dome-shaped window $(45 \mathrm{~cm}$ wide and $27 \mathrm{~cm}$ high) in one 236 panel. Insects entering the trap tend to fly upwards until they fall into the collecting bottle (500 $237 \mathrm{ml}$ ) half-filled with a $30 \%$ ethanol solution with $5 \mu \mathrm{l} / 1$ detergent (Teepol $610 \mathrm{~S}$, ref 86350, 238 Sigma-Aldrich) to kill and preserve the catch. Four tent traps were set up (two facing the bare 239 soil and two facing the flower strips) for 5-6 weeks of monitoring. Collecting bottles were changed weekly.

241 Arthropods collected by the three trapping methods were stored in $70 \%$ ethanol until taxonomic 242 identification under a stereomicroscope. Generalist predators (Aeolothripidae (Thysanoptera), 243 Anthocoridae, Lygaeoidae, Miridae and Nabidae (Hemiptera), Carabidae and Staphylinidae 244 (Coleoptera), Dermaptera, Arachnids (spiders)) and specialist predators (Coccinellidae 245 (Coleoptera), Neuroptera, Syrphidae (Diptera)) were identified to the taxonomic level required 246 to know their feeding behavior and counted.

2.3. Data analysis

\subsubsection{Biotests under controlled conditions}

251 No-choice settling tests were performed to evaluate the capacity of 18 candidate plant species 252 to host two aphid species (Aphis gossypii and Myzus persicae). For each aphid species, a Chi- 
square test was conducted to determine if the plant species affected the acceptance rate

254 (proportion of aphids recovered 24h after deposition). When the null hypothesis of equality was

255 rejected, the Marascuilo procedure for pairwise multiple comparisons was applied. The effect

256 of the plant species on the reproductive rate (number of offspring per recovered aphid) was

257 investigated through nonparametric Kruskal-Wallis tests. When the null hypothesis of equality

258 was rejected, Dunn's pairwise multiple comparisons were performed using the Bonferroni

259 correction.

260 Transmission tests were performed to evaluate the capacity of the candidate plant species to

261 host four viruses (CABYV, CMV, WMV and ZYMV). For each virus, a Chi-square test was

262 conducted to determine if the plant species affected the transmission rate. When the null

263 hypothesis of equality was rejected, the Marascuilo procedure for pairwise multiple

264 comparisons was applied.

265 All statistical analyses were performed using XLSTAT (version 2015.4.01, Addinsoft, Paris).

\subsubsection{Field experiments}

268 Depending on the trapping method used to monitor aphid predators and thus the main taxa 269 caught, statistical analyses were conducted on different categories: spiders for pitfall traps; generalist predators and specialist predators for vacuum sampling and flight interception traps.

271 For this latter trapping method, the abundance of specialist predators was further separated into

272 Coccinellidae, Neuroptera and Syrphidae.

273 For pitfall trapping and vacuum sampling, we first tested the independence of catches between 274 dates and years using a Spearman's correlation test (for each kind of field margin separately). 275 As no significant correlation was found, we considered each strip (north and south) and each 276 sampling date as independent values and computed mean values accordingly. We then tested 277 the effect of the management type (flower strip/grass strip and bare soil) and sampling zone 
278 (margin/crop) on abundances using two-way ANOVA (no heteroscedasticity was detected)

279 followed by post hoc multiple comparisons (Tukey HSD). For interception trapping, the effect 280 of the management type (flower strip/bare soil) was investigated through a nonparametric 281 Wilcoxon signed-rank test performed between paired values $(n=22)$. All computations were 282 carried out using R software. 


\section{Results}

284

285 3.1. Plant screening under controlled conditions

3.1.1. Evaluation of the risk of aphid infestation

For A. gossypii, the mean percentage of aphids recovered after $24 \mathrm{~h}$ (acceptance rate) ranged

from 1 to $95 \%$ and the mean number of offspring per recovered aphid (reproductive rate) ranged

290 from 0 to 18.4 (Table 1). The acceptance rates obtained for basil, bullwort and French marigold were not significantly different from that obtained for melon $\left(\chi^{2}=1729\right.$, df $=18$, p-value <

0.0001). The reproductive rates for borage, bullwort, lacy phacelia were not significantly different from that obtained for melon (Kruskal-Wallis test: $\mathrm{K}=293$, $\mathrm{df}=18$, p-value $<0.0001$ ).

For $M$. persicae, the mean acceptance rate ranged from 0 to $97 \%$ and the mean reproductive rate ranged from 0 to 6.0 (Table 1). The acceptance rates obtained for borage, bullwort, corn $=1832, \mathrm{df}=19, \mathrm{p}$-value $<0.0001)$. The reproductive rates for borage, corn marigold, dill, field marigold, lacy phacelia were not significantly different from that obtained for pepper $(K=293$, $\mathrm{df}=19$, $\mathrm{p}$-value $<0.0001)$. A plant species was considered as a suitable host for an aphid species when its acceptance rate and/or reproductive rate were not significantly different from the reference rates obtained on plant species used for aphid rearing (melon for A. gossypii and pepper for $M$. persicae). Thus, in the case of $A$. gossypii, five species were accepted as hosts: 303 basil, borage, bullwort, French marigold and lacy phacelia (Table 1). M. persicae was able to 304 use six species as hosts: borage, bullwort, corn marigold, dill, field marigold and lacy phacelia

305 (Table 1). Considering the potential impact they could have on A. gossypii and/or M. persicae 306 populations and subsequently on virus transmission, eight plant species were considered high 
risk for melon crops: basil, borage, bullwort, corn marigold, dill, field marigold, French

308 marigold and lacy phacelia.

\subsubsection{Evaluation of the risk of virus infection}

311 A plant species was considered a virus host when its transmission rate was not significantly 312 different to the reference rate obtained on melon (Table 2). Dill was the only host for CABYV $313\left(\chi^{2}=58, \mathrm{df}=18, \mathrm{p}\right.$-value $\left.<0.0001\right)$. Eleven plant species were infected with CMV: basil, 314 borage, buckwheat, corn marigold, cornflower, French marigold, lacy phacelia, marigold, 315 nigella, sweet marjoram and white campion $\left(\chi^{2}=139\right.$, $\mathrm{df}=18$, p-value $\left.<0.0001\right)$. Six plant species were infected with both WMV isolates: buckwheat, bullwort, dill, field marigold, lacy

317 phacelia and nigella (LL1A: $\chi^{2}=152$, df $=18$, p-value $<0.0001$; LL2B3: $\chi^{2}=153$, df $=18$, p318 value < 0.0001). Three plant species were infected with both ZYMV isolates: bullwort, dill and 319 nigella (E9 and 124L11: $\chi^{2}=155, \mathrm{df}=18$, p-value $<0.0001$ ). Taking into account the relative 320 harmfulness of the four viruses, plant species capable of hosting WMV and/or ZYMV were 321 considered a high risk for melon crops. These were buckwheat, bullwort, dill, field marigold, 322 lacy phacelia and nigella.

324 3.1.3. Combining risks of aphid infestation and virus infection to select plant species

325 Ten plant species, which showed a high risk for both aphid infestation and virus infection 326 according to biotests, were discarded from the selection: basil, borage, buckwheat, bullwort, 327 corn marigold, dill, field marigold, French marigold, lacy phacelia and nigella. Three additional 328 plant species previously reported to be aphid hosts (Table S1) were also discarded: marigold, 329 ryegrass and white campion. 
The remaining five species (cornflower, grass pea, sainfoin, salad burnet and sweet marjoram)

331 were selected and combined in a seed mix with the expertise of a seed seller and tested in situ.

333 3.2. In situ evaluation of the flowering capacity of the seed mix

335 Over the course of our five-year experiment, cornflower, grass pea, sainfoin, salad burnet 336 established first and constituted the higher vegetation strata; sweet marjoram generally appeared later, constituting the low stratum. At melon planting, nearly all strips had $100 \%$ plant cover. Flowering spanned the entire melon cropping period (Table 3). Grass pea was generally the only flowering plant species at melon planting. It started to flower around mid-May and

340 was abundant until the end of June. The flowering of cornflower generally started shortly after 341 melon planting and lasted until the end of July with a peak at mid-crop. Sainfoin and salad 342 burnet flowered between mid-June and the end of July. Sweet majoram had a short flowering 343 period centered around mid-July. Thus, the five-species mix allowed a flowering continuum 344 likely to provide a food resource continuum conducive to the development of natural enemies.

346 3.3. In situ evaluation of aphid predator abundance in field margins and melon crop

\subsubsection{Pitfall trapping}

349 Both the management type and the sampling location (field margin vs crop) had a significant 350 effect on spider abundance ( $\mathrm{p}$-value $=0.0018$ and $\mathrm{p}$-value $=0.0020$, respectively). Within the 351 field margins, the mean number $( \pm$ SEM) of spiders trapped per week was significantly higher 352 in the flower strip $(36.1 \pm 2.7)$ than in bare soil $(11.3 \pm 2.3)$ which corresponds to an average 353 increase of $219 \%$ (Figure 2). Spider abundance was intermediate in grass strip (22.6 \pm 1.6$)$ 
354 (Figure 2). Within the melon crop, no difference was observed between the field margin 355 management modalities. The mean numbers of spiders trapped per week ranged from $10.0 \pm$ 3561.0 to $15.7 \pm 4.0$, i.e. similar to that assessed in bare soil (Figure 2).

\subsubsection{Vacuum sampling}

359 The abundance of generalist predators was significantly affected by both the management type 360 (p-value $=0.026)$ and the sampling location $(\mathrm{p}$-value $<0.001)$. There was also a significant 361 management type*sampling location interaction $(\mathrm{p}$-value $=0.037)$ indicating that the effect of 362 management type changed according to sampling location. Within the field margins, the mean 363 number of generalist predators trapped per suction was significantly higher in the flower strip $364(18.3 \pm 5.4)$ than in bare soil $(3.3 \pm 0.6)$ which corresponds to an average increase of $455 \%$ 365 (Figure 3a). The abundance of generalist predators was intermediate in grass strip (13.1 \pm 4.1$)$ 366 (Figure 3a). Within the melon crop, in contrast, the effect of management type was not 367 significant with abundances ranging from $3.2 \pm 0.7$ to $4.1 \pm 0.8$ individuals trapped per suction 368 (Figure 3a).

369 The abundance of specialist predators was significantly affected by both the management type 370 (p-value $<0.001)$ and the sampling location $(\mathrm{p}$-value $=0.0045)$. There was also a significant 371 management type*sampling location interaction $(\mathrm{p}$-value $=0.035)$. Within the field margins, 372 the mean number of specialist predators trapped per suction was significantly higher in the 373 flower strip $(5.8 \pm 1.0)$ than in the grass strip $(2.0 \pm 1.1)$ or bare soil $(0.6 \pm 0.3)$ which 374 corresponds to an average increase of $813 \%$ in flower strip compared to bare soil (Figure $3 b$ ). 375 Within the melon crop, the effect of management type was not significant with abundances 376 ranging from $0.5 \pm 0.2$ to $2.0 \pm 0.8$ individuals trapped per suction (Figure $3 b$ ). Specialist 
predators collected by vacuum sampling were mostly coccinellids (91\%), rarely lacewings (8\%)

378 and syrphids (1\%) (data not shown).

\subsubsection{Interception trapping}

381 Tent traps facing flower strips intercepted significantly more aphid predators than those facing

382 bare soil: $+95 \%$ for generalist predators (Wilcoxon signed-rank test: $V=191$, p-value $=0.009$ ),

$383+174 \%$ for specialist predators $(\mathrm{V}=166$, $\mathrm{p}$-value $=0.005)$ (Figure 4$)$. Specialist predators 384 (coccinellids, lacewings, syrphids) represented 20-27\% of total predators. The impact of the 385 field margin management type varied depending on the taxa: the mean numbers of coccinellids 386 and syrphids trapped per week were significantly enhanced near flower strips compared to bare 387 soil $(\mathrm{V}=162$, $\mathrm{p}$-value $=0.034$ and $\mathrm{V}=133.5$, $\mathrm{p}$-value $=0.001$, respectively $)$, whereas the effect 388 on lacewings was not significant $(\mathrm{V}=42$, $\mathrm{p}$-value $=0.15)$.

\section{Discussion}

392 In this study, we implemented a multi-step plant selection process to design flower strips 393 adapted to melon crops. In a first step, we evaluated the capacity of 18 candidate plant species 394 to host A. gossypii and/or M. persicae. Host plants could harbor and increase the populations of 395 these aphid species, thus generating pest and vector reservoirs near the crop. Based on our 396 results under controlled conditions, eight plant species were considered a high risk for aphid 397 infestation for melon crops and ruled out: borage, bullwort, corn marigold, dill, field marigold, 398 French marigold and lacy phacelia. These are new host descriptions for A. gossypii (bullwort, 399 lacy phacelia) and M. persicae (borage) compared to previous reports (Blackman and Eastop, 400 2006; Kavallieratos et al., 2007). In a second step, we evaluated the capacity of the same 18 
401 candidate plant species to host the most frequently observed viruses in melon crops in France:

402 CABYV, CMV, WMV and ZYMV. Under controlled conditions, 15 plant species showed 403 systemic infection by at least one virus. These are new host descriptions for CABYV (dill), 404 CMV (nigella, sweet marjoram), WMV (buckwheat, dill, field marigold and nigella) and 405 ZYMV (dill, nigella) compared to the literature (Desbiez and Lecoq, 1997; Edwardson and 406 Christie 1991; Edwardson and Christie, 1997; Lecoq et al., 1992). For CMV, this extends the 407 already tremendous host list reporting 1287 species in 518 genera of 100 families (Edwardson 408 and Christie, 1997). Taking into account the relative harmfulness of the four viruses (Lecoq and 409 Desbiez, 2012), plant species capable of hosting WMV and/or ZYMV were ruled-out as a 410 priority: buckwheat, bullwort, dill, field marigold, lacy phacelia and nigella. Morales et al. 411 (2006) adopted a similar precautionary principle to select insectary plants suitable for growing 412 in tomato crops and discarded plant species likely to be a reservoir for Potato virus Y and CMV. 413 In a third step, we combined biotest results and literature to take into account potential aphid 414 and virus infection risks not revealed in our study.

415 Like in a "guess who?” game, plant species presenting a risk regarding A. gossypii (melon pest 416 and virus vector) and $M$. persicae (virus vector), and a risk regarding the most harmful viruses 417 (WMV and ZYMV) were in turn removed from the candidate list. The remaining five species 418 (cornflower, grass pea, sainfoin, salad burnet and sweet marjoram) were selected and combined 419 in a seed mix to be further tested in situ. It is noteworthy that outsiders made it through the 420 selection while plant species frequently cited in habitat management literature were ruled-out 421 during the process. Such was the case for buckwheat and lacy phacelia which have been given 422 much attention since the 1990s due to the large quantities of nectar and pollen they produce 423 (Fiedler et al., 2008; Laubertie et al., 2012; Robinson et al., 2008; White et al., 1995). The same 424 applies for bullwort and dill, plants of the Apiaceae family considered some of the best nectar 425 sources. Indeed, due to their small open flowers accessible to short-tongued insects, they attract 
a guild of beneficial insects, including syrphids, small parasitic wasps but also lacewings and

427 coccinellids (Fiedler et al., 2008; Laubertie et al., 2012). These plant species, however, appeared

428 clearly unsuitable for melon crops. In addition to being a host for A. gossypii and M. persicae,

429 buckwheat and lacy phacelia combined risks to CMV and WMV, bullwort combined risks to

430 CMV, WMV and ZYMV, and dill exhibited the maximal virus risk, as a suitable host for

431 CABYV, CMV, WMV and ZYMV.

432 Under our pedoclimatic conditions, the five-species mix sown two months before melon 433 planting was effective for establishing field margins with a dense heterogenous plant cover and

434 a flowering continuum spanning the whole crop. As recently reviewed by Gontijo (2019),

435 structurally complex habitats can improve predator survival by providing shelter with a suitable

436 microclimate during summer (cooler temperature and higher humidity) and reduced intraguild

437 predation (either by reducing the chances of direct encounters or by sheltering multiple

438 alternative prey). In addition, the flowering continuum is likely to provide a food resource

439 continuum (nectar, pollen) for natural enemies although the quality and quantity of each

440 constitutive component might be different. In our case, cornflower appeared particularly

441 interesting. First, its abundant flowering spanned the entire melon cropping period. Second, in

442 addition to floral nectar and pollen, it has extrafloral nectaries (Weber et al., 2015) accessible

443 to insects such as syrphids and lacewings (Gilbert, 1981; Limburg and Rosenheim, 2001).

444 Moreover, it hosts a specific aphid Uroleucon jaceae, which is harmless to melon crops. Large

445 colonies of this aphid developed during the vegetative growth of the cornflower and attracted

446 numerous specialist predators such as coccinellids (Figure 1b). Such alternative preys and/or

447 their honeydew allow predator populations to build up prior to melon planting thus enhancing

448 the chances of success for biological regulation (Gontijo, 2019).

449 Three complementary trapping methods were used to monitor generalist and specialist 450 predators: pitfall traps and vacuum sampling to assess the attractiveness of the different field 
margins and the melon crop itself, and interception traps to assess the movement of predators

452 from the margins to the crop. The abundance of spiders assessed by pitfall trapping was highly

453 dependent on the vegetation type. There were respectively 1.6 and 3.2 times more spiders

454 caught in grass and flower margins than in bare soil. Other authors previously observed that

455 bare soil hosted fewer spiders than grassy zones in olive groves (Paredes et al., 2013) and

456 vineyards (Costello and Daane, 1998) and that flower strip implementation resulted in even

457 higher abundances than grass margins (Fernandez et al., 2008; Marko and Keresztes, 2014;

458 Samu, 2003). Within the melon crop, on the contrary, the effect of field margin management

459 was not significant. Spiders concentrated within the flower and grass strips and did not seem to

460 spread much within the melon crop. These results are in agreement with those of Ditner et al.

461 (2013) who observed that, despite high spider abundance in flower margins, their abundance

462 was low in cabbage fields at two distances from the flower margins. This low dispersion of spiders from the field margins towards the crop may be due to both a low attractiveness of the may be more suitable (shelter and microclimatic effects) and/or contain more potential prey 466 (Gontijo, 2019). This high attractiveness of the field margins was also obvious for other 467 generalist predators and specialist predators caught by vacuuming. Generalist predators 468 (including spiders) and aphid specialist predators were respectively 5.5 and 9.1 times more 469 abundant in flower margins than in bare soil. Canopy structure and composition, especially the 470 presence of flowers, appear to be the main drivers of generalist and specialist predator 471 populations as observed in other agro-ecological contexts (Gontijo et al., 2013; Mansion472 Vaquié et al., 2017). For syrphids, flowers are complementary food resources which, in addition 473 to aphid prey, are necessary to complete their life-cycle: larvae are aphidophagous but adults 474 feed on pollen and nectar (Gilbert, 1981). Nectar sugars are fuel for flight and pollen proteins 475 are necessary for egg maturation. For omnivorous coccinellids and lacewings, flowers are 
substitutable resources since larvae and adults consume both plant material and prey. For

477 instance, Robinson et al. (2008) observed that the presence of buckwheat flowers enhanced the 478 longevity and fecundity of the lacewing Micromus tasmaniae when aphid prey was low. In our 479 study, specialist predators collected by vacuum sampling were mostly coccinellids (91\%), 480 rarely lacewings (8\%) and syrphids (1\%). Lacewings are mainly nocturnal (Vas et al., 1999) 481 whereas samplings were made in the morning explaining their low representativeness. Syrphids 482 larvae also show nocturnal behavior and adults may have easily escaped vaccum sampling due 483 to their fast flight. The effect of flower strips on lacewing and syrphid abundance is therefore 484 better assessed through interception trapping. This third trapping method allowed us to assess 485 arthropods moving from the margins to the crop. Fluxes of generalist and specialist predators 486 moving from flower strips to the melon crop were significantly increased compared to bare soil. 487 Manipulating floral resources was particularly beneficial for coccinellids and syrphids. Other 488 studies reported enhanced abundances of these natural enemies in vegetables cultivated with 489 flower strips. Ribeiro and Gontijo (2017) showed that intercropping alyssum (Lobularia 490 maritima L.) with collards (Brassica oleracea L.) contributed to increase the abundance of 491 generalist predators, including coccinellids and syrphids, which translated into a significant 492 reduction in collard pests, especially aphids. Similarly, White et al. (1995) showed that sowing 493 phacelia around the borders of cabbage crops significantly increased syrphid populations and 494 decreased aphid populations. Using field cages, Hogg et al. (2011) showed that the presence of 495 alyssum enhanced aphid suppression in lettuce through increased syrphid fecundity. 496 Investigating the optimal spatial distribution of floral resources, Gillespie et al. (2011) 497 confirmed that adult syrphids were active dispersers and that aphids were suppressed up to 50 498 m away from the nearest alyssum strip.

499 To conclude, our results confirmed that flower strips specifically designed for melon crops 500 attracted significantly more aphid predators than grass margins and bare soil, in agreement with 
501 numerous previous studies. Their potential value to promote biocontrol was therefore

502 established. However, the difficult question is whether these natural enemies did migrate in the 503 adjacent crop so that pest regulation can occur. Pitfall traps and vacuum samplings performed 504 within the melon crop both suggested that migration was limited. Results from interception 505 traps, however, indicated enhanced coccinellid and syrphid migration fluxes near flower strips 506 compared to bare soil, suggesting a possible dispersion further in the crop. Whether this 507 potential for regulation resulted in an effective impact on aphid infestation and virus epidemics 508 in melon crops remains unanswered. The fact remains that, like any other pest management 509 strategy, habitat management is not a silver bullet and should be combined with other methods 510 in an integrated pest management program. For melon crops, combining sown flower strips 511 with Vat gene resistance to A. gossypii and the viruses they carry (Boissot et al., 2016; Schoeny 512 et al., 2017) could be an innovative option worth investigating. 


\section{Acknowledgements}

514

515 We thank Joël Béraud, Michel Pascal and the team IEPV for their involvement in field 516 experiments, Patrick Gognalons, Karine Nozeran, Catherine Wipf-Scheibel, Grégory Girardot, 517 Jonathan Gaudin and trainees for their efficient technical assistance. We thank Claude Girerd 518 for valuable discussion about the seed mix, Philippe Nicot and two anonymous reviewers for 519 constructive comments on this manuscript. We also thank Joël Chadoeuf for sound advices 520 concerning statistical analyses. This study was funded by INRA (AAP2010 Gestion durable des 521 résistances-ParcelR), Agence Nationale de la Recherche (ANR-2010-STRA-001-01 VirAphid) 522 and Ministère de l'Agriculture, de l'Alimentation et de l'Environnement (CTPS 25-C-2011-09 523 and CASDAR 12-1278 Agath).

525 Declarations of interest: none 


\section{References}

528 Bass, C., Denholm, I., Williamson, M.S., Nauen, R., 2015. The global status of insect resistance

529 to neonicotinoid insecticides. Pesticide Biochemistry and Physiology 121, 78-87.

530

531 Blackman, R.L., Eastop, V.F., 2000. Aphids on the world's crops. An identification and 532 information guide. Second edition. John Wiley and Sons Ltd, Chichester, England, 466 pp.

534 Blackman, R.L., Eastop, V.F., 2006. Aphids on the world's herbaceous plants and shrubs.

535 Volume 1: host lists and keys. John Wiley and Sons Ltd, Chichester, England, 1024 pp.

Boissot, N., Schoeny, A., Vanlerberghe-Masutti, F., 2016. Vat, an amazing gene conferring resistance to aphids and viruses they carry: from molecular structure to field effects. Frontiers in Plant Science 7, 18.

540

541 Costello, M.J., Daane, K.M., 1998. Influence of ground cover on spider populations in a table 542 grape vineyard. Ecological Entomology 23, 33-41.

544 Desbiez, C., Lecoq, H., 1997. Zucchini yellow mosaic virus. Plant Pathology 46, 809-829. 545

546 Ditner, N., Balmer, O., Beck, J., Blick, T., Nagel, P., Luka, H., 2013. Effects of experimentally 547 planting non-crop flowers into cabbage fields on the abundance and diversity of predators. 548 Biodiversity and Conservation 4, 1049-1061. 
550 Edwardson, J.R., Christie, R.G., 1991. Watermelon mosaic virus-II. In: The Potyvirus group.

551 Volume III. University of Florida Monograph 16-III, pp1015-1034.

552

553 Edwardson, J.R., Christie, R.G., 1997. Cucumber mosaic Virus In: Viruses infecting peppers

554 and other solanaceous crops. Volume I. University of Florida Monograph 18-1, pp133-159.

555

556 Fernandez D.E., Cichon, L.I., Sanchez, E.E., Garrido, S.A., Gittins C., 2008. Effect of different cover crops on the presence of arthropods in an organic apple (Malus domestica Borkh) orchard. Journal of Sustainable Agriculture 2, 197-211.

560 Fiedler, A.K., Landis, D.A., Wratten, S.D., 2008. Maximizing ecosystem services from 561 conservation biological control: the role of habitat management. Biological Control 45, 254562 271.

564 Gilbert, F.S., 1981. Foraging ecology of hoverflies: morphology of the mouthparts in relation 565 to feeding on nectar and pollen in some common urban species. Ecological Entomology 6, 245566262.

567

568 Gillespie, M., Wratten, S., Sedcole, R., Colfer, R., 2011. Manipulating floral resources 569 dispersion for hoverflies (Diptera: Syrphidae) in a California lettuce agro-ecosystem. Biological 570 Control 59, 215-220.

572 Gontijo, L.M., 2019. Engineering natural enemy shelters to enhance conservation biological control in field crops. Biological Control 130, 155-163. 
575 Gontijo, L.M., Beers, E.H., Snyder, W.E., 2013. Flowers promote aphid suppression in apple 576 orchards. Biological Control 66, 8-15.

577

578 Gurr, G.M., Wratten, S.D., Altieri, M.A., 2004. Ecological engineering for pest management. 579 Advances in habitat manipulation for arthropods, 244 pp. CSIRO Publishing, Collingwood, 580 Australia.

581

582 Gurr, G.M., Wratten, S.D., Landis, D.A., You, M.S., 2017. Habitat management to suppress 583 pest populations: progress and prospects. Annual Review of Entomology 62, 91-109. 584

Hogg, B.N., Nelson, E.H., Mills, N.J., Daane, K.M., 2011. Floral resources enhance aphid 586 suppression by a hoverfly. Entomologia Experimentalis et Applicata 141, 138-144.

587

Kavallieratos, N.G., Tomanovic, Z., Sarlis, G.P., Vayias, B.J., Zikic, V. and Emmanouel, N.E., 589 2007. Aphids (Hemiptera: Aphidoidea) on cultivated and self-sown plants in Greece. Biologia 590 $62,335-344$.

591

592 Landis, D.A., Wratten, S.D., Gurr, G.M., 2000. Habitat management to conserve natural 593 enemies of arthropod pests in agriculture. Annual Review of Entomology 45, 175-201. 594

595 Laubertie, E.A., Wratten, S.D., Hemptinne, J.L., 2012. The contribution of potential beneficial 596 insectary plant species to adult hoverfly (Diptera: Syrphidae) fitness. Biological Control 61, 1597 6. 
Lecoq, H., Bourdin, D., Wipf-Scheibel, C., Bon, M., Lot, H., Lemaire, O., Herrbach, E., 1992.

600 A new yellowing disease of cucurbits caused by a luteovirus, cucurbit aphid-borne yellows 601 virus. Plant Pathology 41, 749-761.

602

603 Lecoq, H., Desbiez, C., 2012. Viruses of cucurbit crops in the Mediterranean region: an ever604 changing picture. Advances in Virus Research 84, 67-126.

605

606 Limburg, D.D., Rosenheim, J.A., 2001. Extrafloral nectar consumption and its influence on the 607 survival and development of an omnivorous predator, larval Chrysoperla plorabunda 608 (Neuroptera: Chrysopidae). Environmental Entomology 30, 595-604.

609

610 Losey, J.E., Vaughan, M., 2006. The economic value of ecological services provided by insects. 611 BioScience 56, 311-323.

612

613 Mansion-Vaquié, A., Ferrante, M., Cook, S.M., Pell, J.K., Lövei, G.L., 2017. Manipulating 614 field margins to increase predation intensity in fields of winter wheat (Triticum aestivum). 615 Journal of Applied Entomology 141, 600-611.

616

617 Marko V., Keresztes B., 2014. Flowers for better pest control? Ground cover plants enhance 618 apple orchard spiders (Araneae), but not necessarily their impact on pests. Biocontrol Science 619 and Technology 24, 574-596.

620

621 Morales, I., Sanchez, J.A., Alomar, O., Lacasa, A., Fereres, A., 2006. Susceptibility to virus 622 infection of candidate plants used to enhance predatory dicyphine (Heteroptera: Miridae). 623 IOBC-WPRS Bulletin 29, 255-260. 
625 Paredes, D., Cayuela, L., Campos M., 2013. Synergistic effects of ground cover and adjacent 626 vegetation on natural enemies of olive insect pests. Agriculture, Ecosystems \& Environment $627 \quad 173,72-80$.

628

629 Perring, T.M., Gruenhagen, N.M., Farrar, C.A., 1999. Management of plant viral diseases 630 through chemical control of insect vectors. Annual Review of Entomology 44, 457-481.

631

632 Ribeiro, A.L., Gontijo, L.M., 2017. Alyssum flowers promote biological control of collard 633 pests. BioControl 62, 185-196.

634

635 Robinson, K.A., Jonsson, M., Wratten, S.D., Wade, M.R., Buckley, H.L., 2008. Implications 636 of floral resources for predation by an omnivorous lacewing. Basic and Applied Ecology 9, $637 \quad 172-181$.

638

639 Samu, F., 2003. Can field-scale habitat diversification enhance biocontrol potential of spiders?

640 Pest Management Science 59, 437-442.

641

642 Schoeny, A., Desbiez, C., Millot, P., Wipf-Scheibel, C., Nozeran, K., Gognalons, P., Lecoq, 643 H., Boissot, N., 2017. Impact of Vat resistance in melon on viral epidemics and genetic structure 644 of virus populations. Virus Research 241, 105-115.

645

646 Tscharntke, T., Karp, D.S., Chaplin-Kramer, R., Batary, P., DeClerck, F., Gratton, C., Hunt, L., 647 Ives, A., Jonsson, M., Larsen, A., Martin, E.A., Martinez-Salinas, A., Meehan, T.D., O'Rourke, 648 M., Poveda, K., Rosenheim, J.A., Rusch, A., Schellhorn, N., Wanger, T.C., Wratten, S., Zhang, 
649 W., 2016. When natural habitat fails to enhance biological pest control - Five hypotheses.

650 Biological Conservation 204, 449-458.

651

652 Thomas, S., Dogimont, C., Boissot, N., 2012. Association between Aphis gossypii genotype 653 and phenotype on melon accessions. Arthropod-Plant Interactions 6, 93-101.

654

655 Vas, J., Abraham, L., Markó, V., 1999. Study of nocturnal and diurnal activities of lacewings

656 (Neuropteroidea: Raphidioptera, Neuroptera) by suction trap. Acta Phytopathologica et 657 Entomologica Hungarica 34, 149-152.

658

659 Weber, M.G., Porturas, L.D., Keeler, K.H., 2015. World list of plants with extrafloral nectaries.

660 http://www.extrafloralnectaries.org/ (accessed 29 January 2018).

661

662 White, A.J., Berry, N.A., Wratten, S.D., Weigmann, U., 1995. Habitat manipulation to enhance 663 biological control of brassica pests by hover flies (Diptera: Syrphidae). Journal of Economic 664 Entomology 88, 1171-1176. 


\section{Figure captions}

666

667 Figure 1 Flower strip composed of five plant species (cornflower, grass pea, sainfoin, salad 668 burnet and sweet marjoram) selected to boost biological control in melon crop (a) Interception 669 trap used to assess the fluxes of aphid predators from the field margin to the crop (b) Adult 670 coccinellid feeding in a colony of Uroleucon jaceae on cornflower. Photo credit: Alexandra 671 Schoeny, INRA

672

673 Figure 2 Abundance of spiders assessed by pitfall trapping, within field margins and melon

674

675

676

677

678

679

680

681

682

683

684

685

686

687

crop, for three types of field margin management, in a field experiment conducted in Avignon.

Pitfalls were placed for one week of monitoring at two dates in 2013 and 2014. Data are means across replicates and dates. Bars show standard errors of the mean. Modalities with same letters are not significantly different according to the post hoc multiple comparison test performed (Tukey HSD, alpha $=0.05)$.

Figure 3 Abundance of generalist predators (a) and aphid specialist predators (b) assessed by vacuum sampling, within field margins and melon crop, for three types of field margin management, in a field experiment conducted in Avignon. Samples were collected at two dates in 2012, 2013 and 2014. Data are means across replicates and dates. Bars show standard errors of the mean. Modalities with same letters are not significantly different according to the post hoc multiple comparison test performed (Tukey HSD, alpha $=0.05$ ). 
688 Figure 4 Fluxes of aphid predators migrating from the field margins to the melon crop assessed 689 by interception trapping, for two types of field margin management, in a field experiment 690 conducted in Avignon. Monitoring was carried out for five weeks in 2014 and six weeks in 691 2015. Data are means across replicates and weeks. Bars show standard errors of the mean. 692 Modalities with same letters are not significantly different according to the Wilcoxon signed693 rank test performed (alpha $=0.05)$. 


\section{Table captions}

695

696 Table 1 Evaluation of the capacity of 20 plant species to host Aphis gossypii and Myzus

697 persicae. The acceptance rate (percentage of aphids recovered after $24 \mathrm{~h}$ ) and the reproductive 698 rate (number of offspring per recovered aphid) were assessed in no-choice settling tests 699 conducted under controlled conditions.

700

701 Table 2 Evaluation of the capacity of 19 plant species to host four viruses frequently observed 702 on melon crops in France. The transmission rate (percentage of infected plants) was assessed through aphid transmission (CABYV) or mechanical inoculation (CMV, WMV, ZYMV) under 704 controlled conditions.

705

706 Table 3 Kinetics of flowering for five plant species composing flower strips evaluated in a field experiment conducted in Avignon between 2011 and 2015. For each plant species, the percentage of plants at flowering stage was monitored at different dates after melon planting. Plants were considered at flowering stage when displaying at least one open flower. Data are means \pm SEM. 


\section{Highlights}

712

713 - We selected five plant species minimizing aphid and virus risks in melon.

714 - We assessed the seed mix in a five-year field experiment.

715 - Sown flower strips displayed a flowering continuum conducive to natural enemies.

716 - Generalist and specialist predators were significantly enhanced in flower strips. 


\section{Figure 1}

718
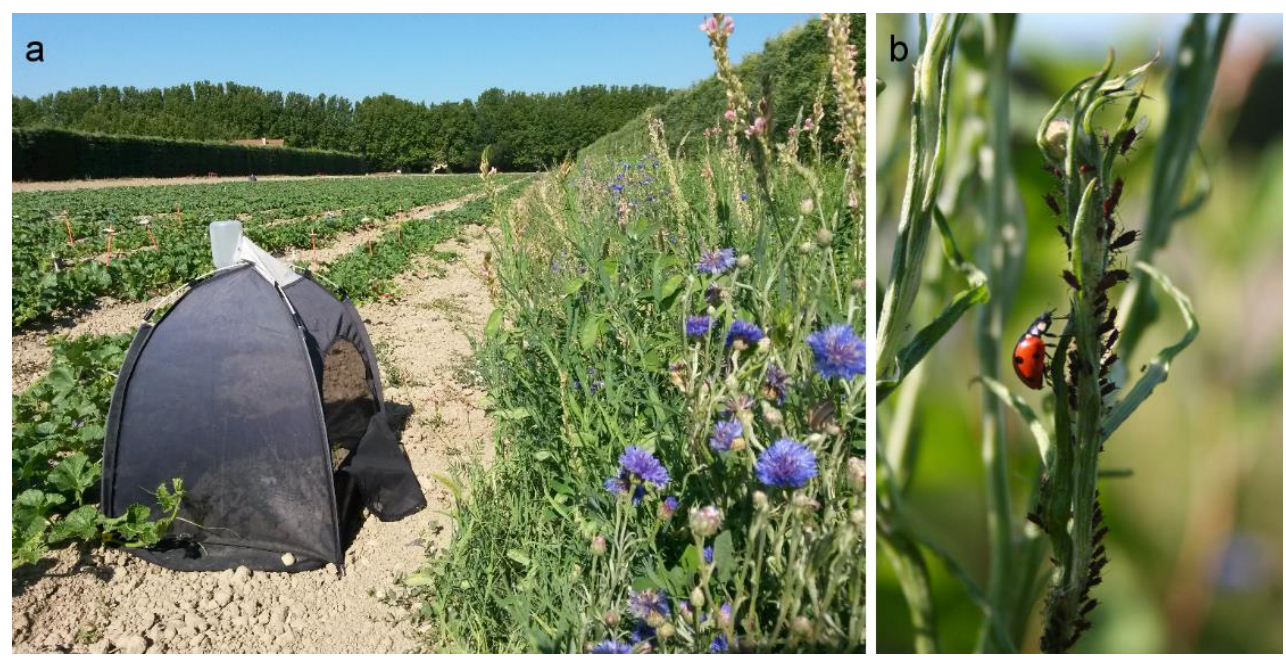


\section{Figure 2}

720

721

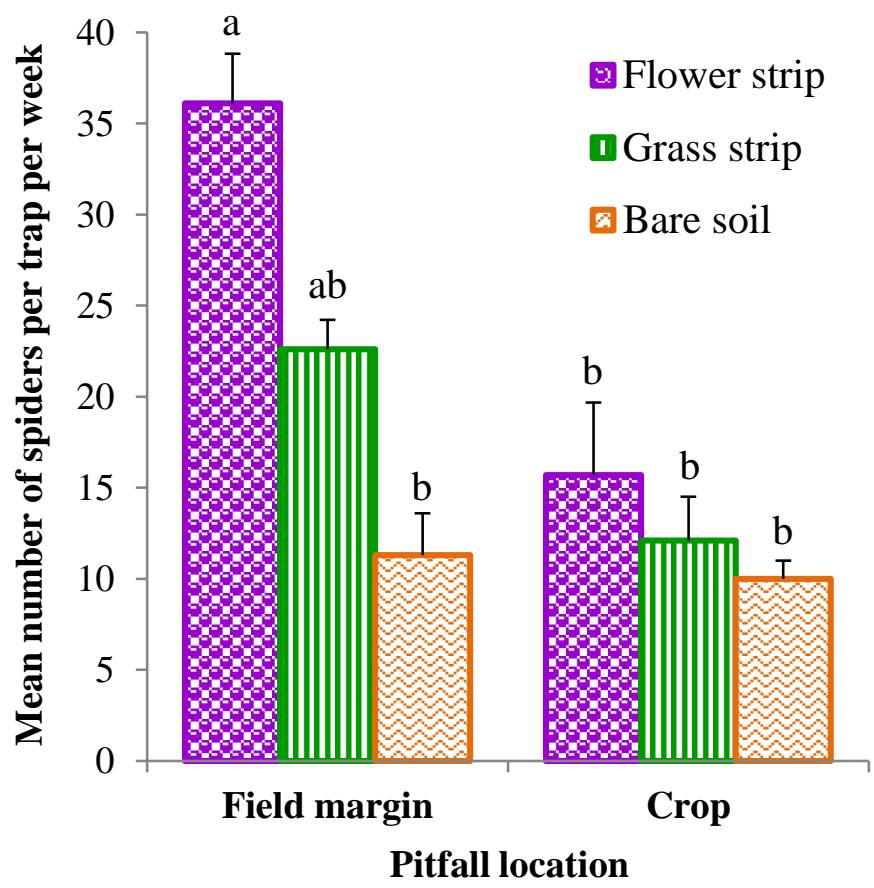




\section{$722 \quad$ Figure 3}

723

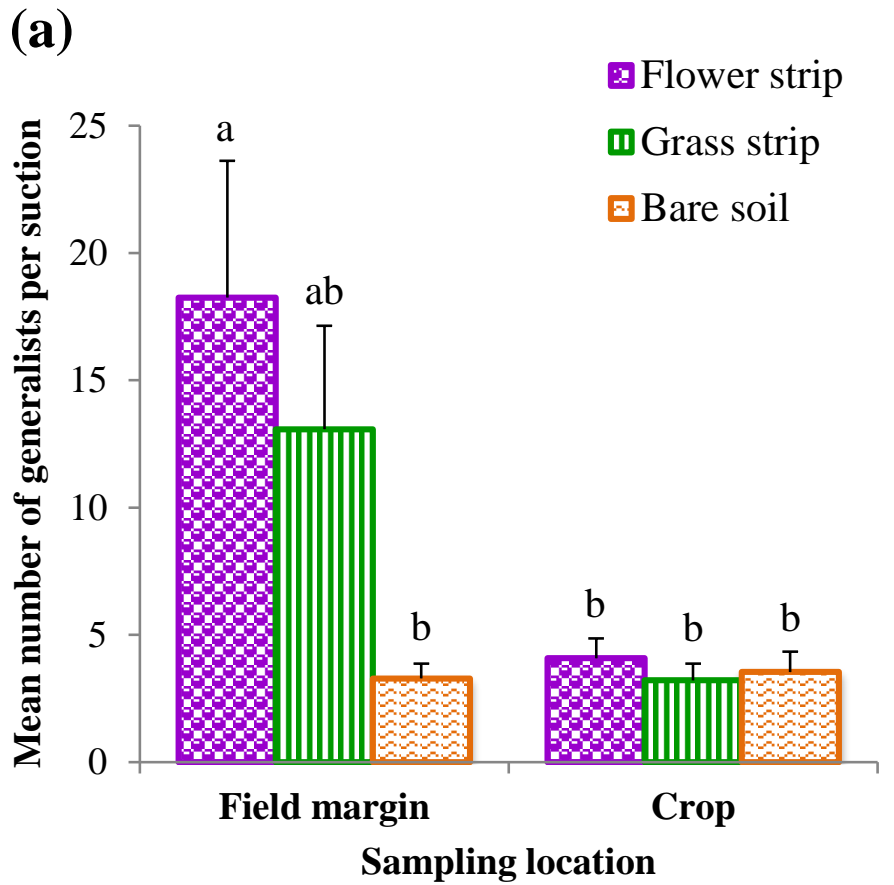

(b)

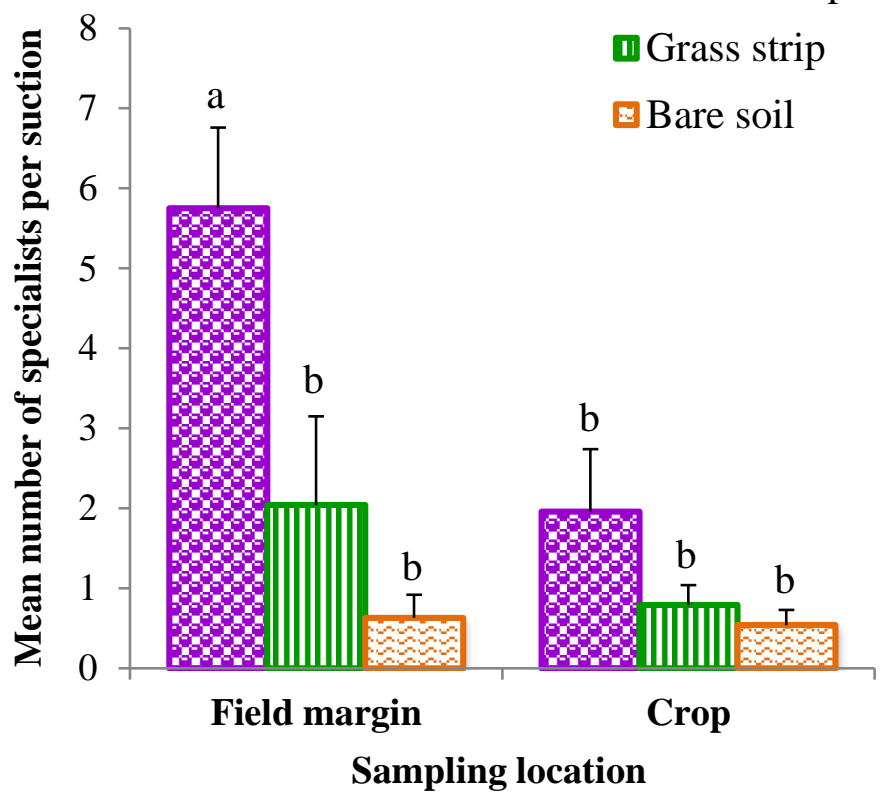




\section{Figure 4}

725

726
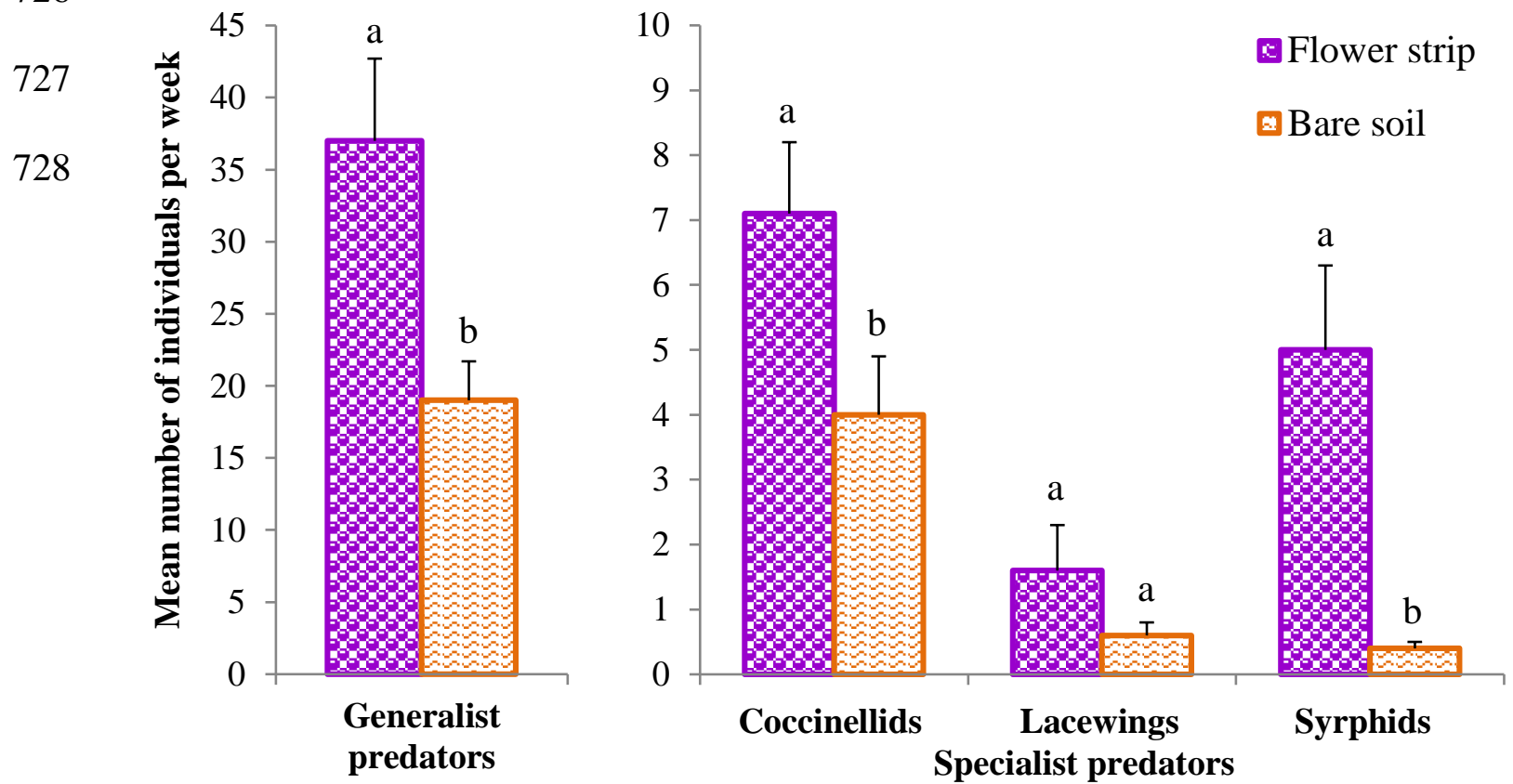


\begin{tabular}{|c|c|c|c|c|c|c|c|c|c|c|c|c|c|c|}
\hline \multirow[b]{3}{*}{ Common name $^{a}$} & \multicolumn{7}{|c|}{ Aphis gossypii } & \multicolumn{7}{|c|}{ Myzus persicae } \\
\hline & \multirow{2}{*}{$\begin{array}{l}\text { Nb tested } \\
\text { plants }\end{array}$} & \multicolumn{3}{|c|}{$\begin{array}{c}\% \text { aphids recovered } \\
\text { after } 24 \mathrm{~h}\end{array}$} & \multicolumn{3}{|c|}{$\begin{array}{l}\text { Nb offspring per } \\
\text { recovered aphid }\end{array}$} & \multirow{2}{*}{$\begin{array}{l}\text { Nb tested } \\
\text { plants }\end{array}$} & \multicolumn{3}{|c|}{$\begin{array}{c}\% \text { aphids recovered } \\
\text { after } 24 \mathrm{~h}\end{array}$} & \multicolumn{3}{|c|}{$\begin{array}{l}\text { Nb offspring per } \\
\text { recovered aphid }\end{array}$} \\
\hline & & Mean & SEM & Group $^{\text {b }}$ & Mean & SEM & Group $^{b}$ & & Mean & SEM & Group $^{\text {b }}$ & Mean & SEM & Group $^{b}$ \\
\hline Basil & 10 & 83 & 6 & $a b$ & 0.0 & 0.0 & $\mathrm{c}$ & 10 & 19 & 4 & def & 0.0 & 0.0 & $\mathrm{~d}$ \\
\hline Borage & 10 & 24 & 6 & defgh & 7.2 & 1.8 & $a b$ & 10 & 95 & 3 & $\mathrm{a}$ & 4.1 & 0.3 & $a b$ \\
\hline Buckwheat & 10 & 3 & 2 & $\mathrm{~h}$ & 2.4 & 2.3 & $\mathrm{bc}$ & 10 & 0 & 0 & $f$ & 0.0 & 0.0 & $\mathrm{~d}$ \\
\hline Bullwort & 10 & 74 & 6 & $a b c$ & 1.5 & 0.3 & $a b c$ & 10 & 90 & 4 & $a b$ & 1.1 & 0.4 & bcd \\
\hline Corn marigold & 10 & 4 & 2 & $\mathrm{~h}$ & 2.6 & 1.3 & $\mathrm{bc}$ & 10 & 74 & 7 & $a b c$ & 2.6 & 0.3 & abcd \\
\hline Cornflower * & 30 & 67 & 7 & $\mathrm{bc}$ & 1.4 & 0.2 & $\mathrm{bc}$ & 30 & 71 & 6 & $\mathrm{bc}$ & 1.6 & 0.4 & bcd \\
\hline Dill & 10 & 12 & 2 & fgh & 0.1 & 0.1 & $\mathrm{c}$ & 10 & 77 & 8 & $a b c$ & 1.5 & 0.4 & abcd \\
\hline Field marigold & 10 & 57 & 7 & bcd & 0.8 & 0.2 & $\mathrm{bc}$ & 10 & 97 & 3 & $\mathrm{a}$ & 1.1 & 0.1 & abcd \\
\hline French marigold & 10 & 71 & 4 & $a b c$ & 0.0 & 0.0 & c & 10 & 31 & 3 & de & 0.2 & 0.1 & bcd \\
\hline Grass pea $*$ & 20 & 10 & 3 & gh & 0.8 & 0.3 & $\mathrm{bc}$ & 20 & 28 & 5 & de & 1.0 & 0.3 & bcd \\
\hline Lacy phacelia & 10 & 57 & 7 & bcd & 18.4 & 1.3 & $\mathrm{a}$ & 10 & 48 & 11 & $\mathrm{~cd}$ & 4.0 & 0.9 & $a b c$ \\
\hline Marigold & 10 & 21 & 5 & efgh & 0.4 & 0.3 & $\mathrm{bc}$ & 10 & 44 & 6 & $\mathrm{~cd}$ & 0.1 & 0.1 & $\mathrm{~cd}$ \\
\hline Melon ** & 103 & 95 & 1 & $\mathrm{a}$ & 12.0 & 0.6 & $\mathrm{a}$ & 10 & 2 & 2 & $f$ & 0.1 & 0.1 & $\mathrm{~d}$ \\
\hline Nigella & 10 & 1 & 1 & $\mathrm{~h}$ & 0.0 & 0.0 & $\mathrm{c}$ & 10 & 40 & 10 & $\mathrm{~d}$ & 0.8 & 0.2 & bcd \\
\hline Pepper ** & $\mathrm{nt}$ & $\mathrm{nt}$ & $\mathrm{nt}$ & $\mathrm{nt}$ & $\mathrm{nt}$ & $\mathrm{nt}$ & $\mathrm{nt}$ & 94 & 94 & 1 & $\mathrm{a}$ & 6.0 & 0.2 & $\mathrm{a}$ \\
\hline Ryegrass & 20 & 32 & 8 & def & 0.0 & 0.0 & $\mathrm{c}$ & 20 & 9 & 3 & ef & 0.0 & 0.0 & $\mathrm{~d}$ \\
\hline Sainfoin * & 20 & 29 & 8 & defg & 0.0 & 0.0 & c & 20 & 7 & 4 & $f$ & 0.0 & 0.0 & $\mathrm{~d}$ \\
\hline Salad burnet * & 20 & 9 & 2 & gh & 0.2 & 0.1 & $\mathrm{c}$ & 20 & 5 & 2 & $f$ & 0.1 & 0.1 & $\mathrm{~d}$ \\
\hline Sweet marjoram * & 20 & 49 & 11 & cde & 0.0 & 0.0 & c & 20 & 32 & 7 & $\mathrm{~d}$ & 0.1 & 0.1 & $\mathrm{~d}$ \\
\hline White campion & 10 & 10 & 4 & fgh & 0.0 & 0.0 & $\mathrm{c}$ & 10 & 30 & 6 & de & 0.0 & 0.0 & $\mathrm{~d}$ \\
\hline Statistical test & & & & Chi2 & & & KW & & & & Chi2 & & & $\mathrm{KW}$ \\
\hline P-value & & & & $<0,0001$ & & & $<0,0001$ & & & & $<0,0001$ & & & $<0,0001$ \\
\hline
\end{tabular}


731 a Plant species with an asterisk are included in the flower mix

732 Plant species with two asterisks are reference species:

733 Melon is reference species for Aphis gossypii risk assessment

734 Pepper is reference species for Myzus persicae risk assessment

$735 \quad{ }^{\mathrm{b}}$ Plants with the same letters are not significantly different

736 Grey zones highlight acceptance and reproductive rates not significantly different to the reference rates obtained on plant species used for aphid rearing 737 (melon for A. gossypii and pepper for M. persicae). 


\begin{tabular}{|c|c|c|c|c|c|c|}
\hline \multirow[b]{3}{*}{ Common name ${ }^{\text {a }}$} & \multicolumn{6}{|c|}{ Virus (isolate) } \\
\hline & $\begin{array}{c}\text { CABYV } \\
\text { (FIP) }\end{array}$ & $\begin{array}{c}\text { CMV } \\
\text { (14) }\end{array}$ & $\begin{array}{c}\text { WMV } \\
\text { (LL1A) }\end{array}$ & $\begin{array}{c}\text { WMV } \\
\text { (LL2B3) }\end{array}$ & $\begin{array}{c}\text { ZYMV } \\
\text { (E9) }\end{array}$ & $\begin{array}{c}\text { ZYMV } \\
\text { (124L11) }\end{array}$ \\
\hline & \multicolumn{6}{|c|}{ Nb infected plants / nb tested plants ${ }^{b}$} \\
\hline Basil & $0 / 8$ b & $6 / 8 a b$ & $0 / 8 \mathrm{~b}$ & $0 / 8 \mathrm{~b}$ & $0 / 8 \mathrm{~b}$ & $0 / 8 \mathrm{~b}$ \\
\hline Borage & $0 / 8$ b & $7 / 8$ a & $0 / 8 \mathrm{~b}$ & $0 / 8$ b & $0 / 8 \mathrm{~b}$ & $0 / 8 \mathrm{~b}$ \\
\hline Buckwheat & $0 / 8$ b & $14 / 16$ a & $10 / 16 a b$ & $11 / 16$ a & $0 / 8 \mathrm{~b}$ & $0 / 8 \mathrm{~b}$ \\
\hline Bullwort & $0 / 8$ b & $0 / 8 \mathrm{~b}$ & $8 / 8$ a & $8 / 8$ a & $8 / 8$ a & $8 / 8$ a \\
\hline Corn marigold & $0 / 8 \mathrm{~b}$ & $6 / 6$ a & $0 / 6 \mathrm{~b}$ & $0 / 6 \mathrm{~b}$ & $0 / 6 \mathrm{~b}$ & $0 / 6 \mathrm{~b}$ \\
\hline Cornflower * & $0 / 8 \mathrm{~b}$ & $13 / 16$ a & $0 / 8 \mathrm{~b}$ & $0 / 8 \mathrm{~b}$ & $0 / 8 \mathrm{~b}$ & $0 / 8 \mathrm{~b}$ \\
\hline Dill & $3 / 8$ a & $0 / 8 \mathrm{~b}$ & $8 / 8$ a & $8 / 8$ a & $8 / 8$ a & $8 / 8$ a \\
\hline Field marigold & $0 / 8 \mathrm{~b}$ & $8 / 8$ a & $8 / 8$ a & $8 / 8$ a & $0 / 8 \mathrm{~b}$ & $0 / 8 \mathrm{~b}$ \\
\hline French marigold & $0 / 8$ b & $8 / 8$ a & $0 / 8 \mathrm{~b}$ & $0 / 8$ b & $0 / 8 \mathrm{~b}$ & $0 / 8 \mathrm{~b}$ \\
\hline Grass pea $*$ & $0 / 8 \mathrm{~b}$ & $0 / 8 \mathrm{~b}$ & $0 / 8 \mathrm{~b}$ & $0 / 8$ b & $0 / 8 \mathrm{~b}$ & $0 / 8 \mathrm{~b}$ \\
\hline Lacy phacelia & $0 / 8 \quad b$ & $8 / 8$ a & $6 / 6$ a & $6 / 6$ a & $0 / 6 \mathrm{~b}$ & $0 / 6 \mathrm{~b}$ \\
\hline Marigold & $0 / 8 \mathrm{~b}$ & $8 / 8$ a & $0 / 8 \mathrm{~b}$ & $0 / 8 \mathrm{~b}$ & $0 / 8 \mathrm{~b}$ & $0 / 8 \mathrm{~b}$ \\
\hline Melon & $36 / 100$ a & $27 / 28$ a & $27 / 28$ a & $27 / 28$ a & $20 / 20 a$ & $20 / 20 a$ \\
\hline Nigella & $0 / 8$ b & $8 / 8$ a & $8 / 8$ a & $8 / 8$ a & $8 / 8$ a & $8 / 8$ a \\
\hline Ryegrass & $0 / 8 \quad b$ & $0 / 8 \mathrm{~b}$ & $0 / 8 \mathrm{~b}$ & $0 / 8 \quad b$ & $0 / 8 \mathrm{~b}$ & $0 / 8 \mathrm{~b}$ \\
\hline Sainfoin * & $0 / 8 \mathrm{~b}$ & $0 / 6 \mathrm{~b}$ & $0 / 6 b$ & $0 / 6$ b & $0 / 6 \mathrm{~b}$ & $0 / 6 \mathrm{~b}$ \\
\hline Salad burnet * & $0 / 8 \mathrm{~b}$ & $0 / 8$ b & $0 / 8 \mathrm{~b}$ & $0 / 8$ b & $0 / 8 \mathrm{~b}$ & $0 / 8 \mathrm{~b}$ \\
\hline Sweet marjoram * & $0 / 8 \mathrm{~b}$ & $7 / 8$ a & $0 / 7 \mathrm{~b}$ & $0 / 7$ b & $0 / 7 \mathrm{~b}$ & $0 / 7 \mathrm{~b}$ \\
\hline White campion & $0 / 8 \quad b$ & $5 / 6$ a & $0 / 6 \mathrm{~b}$ & $0 / 6$ b & $0 / 6 \mathrm{~b}$ & $0 / 6 \mathrm{~b}$ \\
\hline Statistical test & Chi2 & Chi2 & Chi2 & Chi2 & Chi2 & Chi2 \\
\hline$P$-value & $<0,0001$ & $<0,0001$ & $<0,0001$ & $<0,0001$ & $<0,0001$ & $<0,0001$ \\
\hline
\end{tabular}

740

$741 \quad{ }^{a}$ Plant species with an asterisk are included in the flower mix

$742 \quad{ }^{b}$ Plants with the same letters are not significantly different

743 Grey zones highlight transmission rates not significantly different to the reference rates obtained on

744 melon. 
Table 3

\begin{tabular}{llcccccc}
\hline & & \multicolumn{5}{c}{ Days after melon planting } \\
\cline { 3 - 7 } Common name & Scientific name & {$[\mathbf{1 - 1 0}]$} & {$[\mathbf{1 1 - 2 0}]$} & {$[\mathbf{2 1 - 3 0}]$} & {$[\mathbf{3 1 - 4 0}]$} & {$[\mathbf{4 1 - 5 0 ]}$} & {$[\mathbf{5 1 - 6 0}]$} \\
\hline Cornflower & Centaurea cyanus & $12 \pm 12$ & $56 \pm 14$ & $71 \pm 8$ & $87 \pm 6$ & $73 \pm 7$ & $34 \pm 6$ \\
Grass pea & Lathyrus sativus & $82 \pm 10$ & $97 \pm 3$ & $83 \pm 11$ & $19 \pm 9$ & $2 \pm 1$ & $0 \pm 0$ \\
Sainfoin & Onobrychis viciifolia & $1 \pm 1$ & $21 \pm 7$ & $43 \pm 6$ & $45 \pm 9$ & $50 \pm 14$ & $42 \pm 3$ \\
Salad burnet & Sanguisorba minor & $0 \pm 0$ & $8 \pm 3$ & $31 \pm 8$ & $20 \pm 7$ & $21 \pm 10$ & $39 \pm 7$ \\
Sweet marjoram & Origanum majorana & $0 \pm 0$ & $0 \pm 0$ & $0 \pm 0$ & $2 \pm 2$ & $28 \pm 19$ & $2 \pm 2$ \\
\hline
\end{tabular}

746 


\section{Graphical abstract}

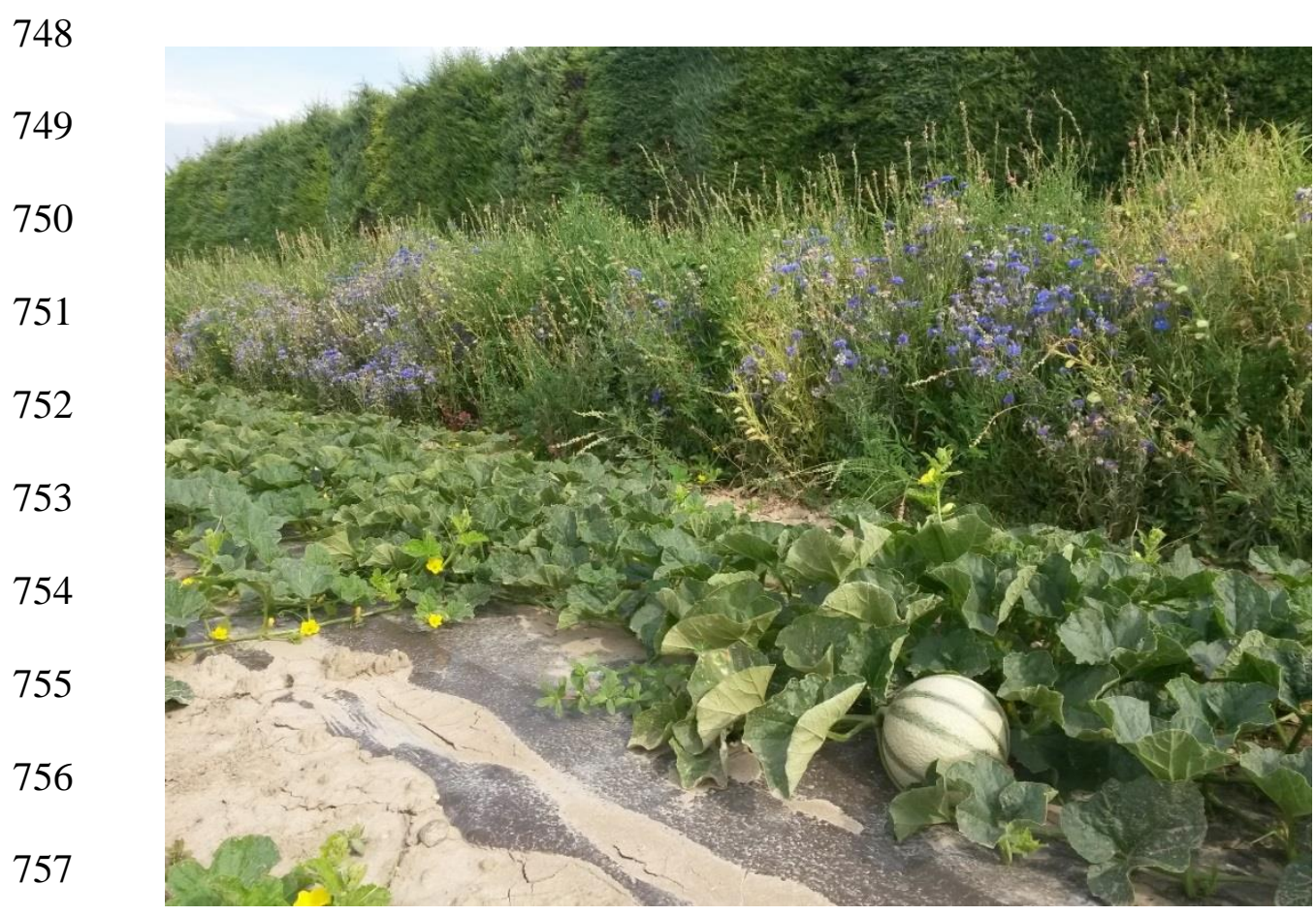

758 
Supplementary material

Figure S1 Schematic representation of the experimental design with spatial pattern of arthropod samplings in field margins and melon crop in 2014

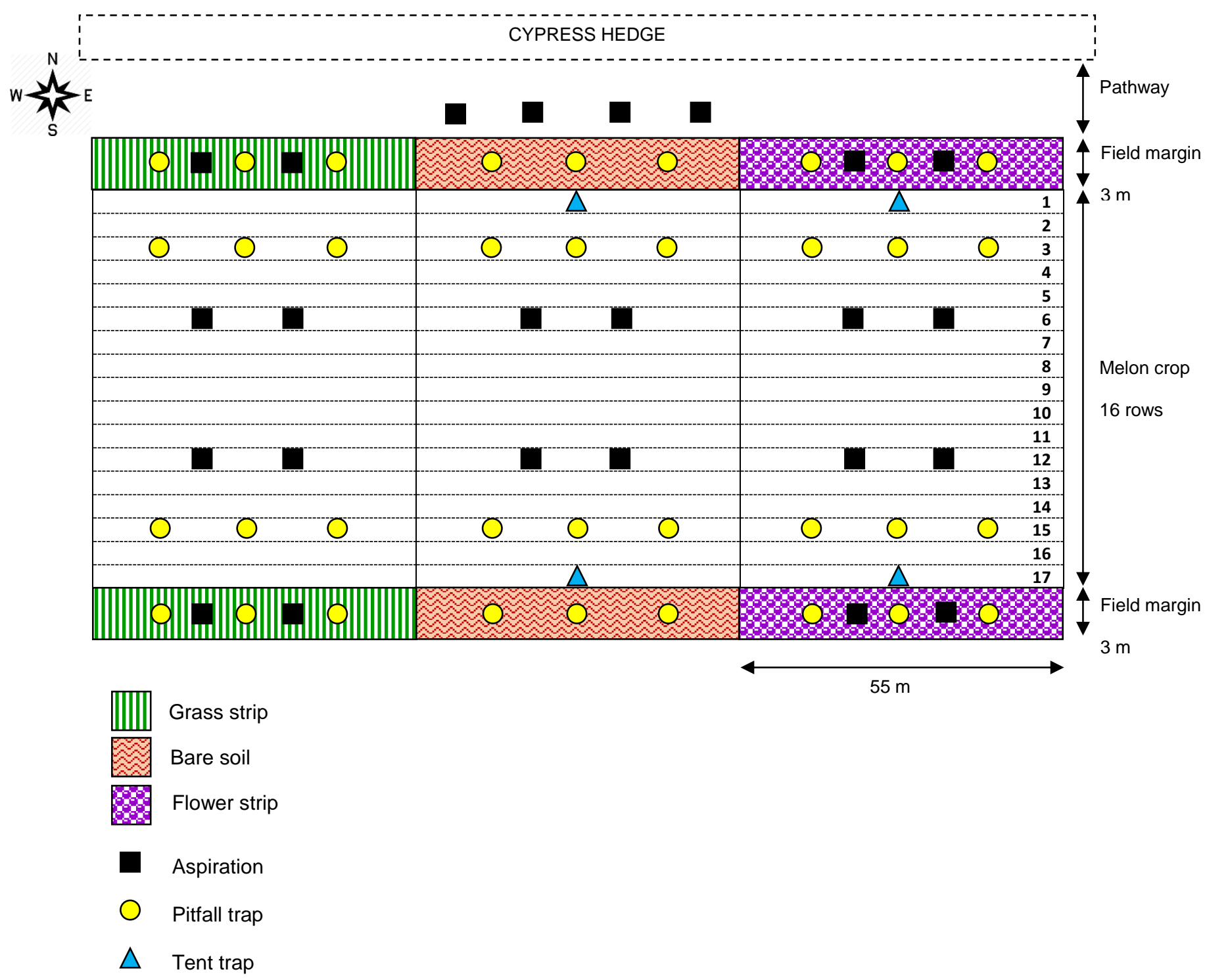


Supplementary material

Table S1 Biotests conducted in controlled conditions to evaluate the capacity of 20 plant species to host two aphid species and and four viruses frequently observed on melon crops in France

\begin{tabular}{|c|c|c|c|c|c|c|c|c|}
\hline \multirow[b]{2}{*}{ Common name ${ }^{a}$} & \multirow[b]{2}{*}{ Scientific name } & \multirow[b]{2}{*}{ Botanical family } & \multirow{2}{*}{$\begin{array}{l}\text { Nb of weeks } \\
\text { after sowing }\end{array}$} & \multicolumn{2}{|c|}{ Aphid risks ${ }^{c}$} & \multicolumn{2}{|c|}{ Virus risks $^{d}$} & \multirow[b]{2}{*}{ Global risks ${ }^{\text {e }}$} \\
\hline & & & & Biotests & Literature & Biotests & Literature & \\
\hline Basil & Ocimum basilicum $\mathrm{L}$. & Lamiaceae & 6-7 & $\mathrm{Ag}$ & $\mathrm{Ag}, \mathrm{Mp}$ & $\mathrm{C}$ & $\mathrm{C}, \mathrm{W}$ & $\mathrm{Ag}, \mathrm{Mp}, \mathrm{C}, \mathrm{W}$ \\
\hline Borage & Borago officinalis L. & Boraginaceae & 4 & $\mathrm{Ag}, \mathrm{Mp}$ & $\mathrm{Ag}$ & $\mathrm{C}$ & $\mathrm{C}$ & $\mathrm{Ag}, \underline{\mathrm{Mp}}, \mathrm{C}$ \\
\hline Buckwheat & Fagopyrum esculentum Moench & Polygonaceae & 4 & $\varnothing$ & $\mathrm{Ag}, \mathrm{Mp}$ & $\mathrm{C}, \mathrm{W}$ & $\mathrm{C}$ & $\mathrm{Ag}, \mathrm{Mp}, \mathrm{C}, \underline{\mathrm{W}}$ \\
\hline Bullwort & Ammi majus L. & Apiaceae & 5 & $\mathrm{Ag}, \mathrm{Mp}$ & $\mathrm{Mp}$ & $\mathrm{W}, \mathrm{Z}$ & $\mathrm{C}, \mathrm{W}, \mathrm{Z}$ & $\underline{\mathrm{Ag}}, \mathrm{Mp}, \mathrm{C}, \mathrm{W}, \mathrm{Z}$ \\
\hline Corn marigold & Chrysanthemum segetum $\mathrm{L}$. & Asteraceae & 5 & $\mathrm{Mp}$ & $\mathrm{Mp}$ & $\mathrm{C}$ & $\mathrm{C}$ & $\mathrm{Mp}, \mathrm{C}$ \\
\hline Cornflower * & Centaurea cyanus L. & Asteraceae & $4-5$ & $\varnothing$ & $\varnothing$ & $\mathrm{C}$ & $\mathrm{C}$ & $\mathrm{C}$ \\
\hline Dill & Anethum graveolens $\mathrm{L}$. & Apiaceae & $5-6$ & $\mathrm{Mp}$ & $\mathrm{Ag}, \mathrm{Mp}$ & $\mathrm{CA}, \mathrm{W}, \mathrm{Z}$ & $\mathrm{C}$ & $\mathrm{Ag}, \mathrm{Mp}, \underline{\mathrm{CA}}, \mathrm{C}, \underline{\mathrm{W}}, \underline{\mathrm{Z}}$ \\
\hline Field marigold & Calendula arvensis $\mathrm{L}$. & Asteraceae & $3-5$ & $\mathrm{Mp}$ & $\mathrm{Ag}, \mathrm{Mp}$ & $\mathrm{C}, \mathrm{W}$ & $\mathrm{C}$ & $\mathrm{Ag}, \mathrm{Mp}, \mathrm{C}, \underline{\mathrm{W}}$ \\
\hline French marigold & Tagetes patula $\mathrm{L}$. & Asteraceae & 6 & $\mathrm{Ag}$ & $\mathrm{Ag}, \mathrm{Mp}$ & $\mathrm{C}$ & $\mathrm{C}$ & $\mathrm{Ag}, \mathrm{Mp}, \mathrm{C}$ \\
\hline Grass pea $*$ & Lathyrus sativus L. & Leguminosae & 4 & $\varnothing$ & $\varnothing$ & $\varnothing$ & $\mathrm{C}$ & $\mathrm{C}$ \\
\hline Lacy phacelia & Phacelia tanacetifolia Benth. & Hydrophyllaceae & 4 & $\mathrm{Ag}, \mathrm{Mp}$ & $\mathrm{Mp}$ & $\mathrm{C}, \mathrm{W}$ & $\mathrm{C}, \mathrm{W}$ & $\mathrm{Ag}, \mathrm{Mp}, \mathrm{C}, \mathrm{W}$ \\
\hline Marigold & Calendula officinalis L. & Asteraceae & 5 & $\varnothing$ & $\mathrm{Ag}, \mathrm{Mp}$ & $\mathrm{C}$ & $\mathrm{C}$ & $\mathrm{Ag}, \mathrm{Mp}, \mathrm{C}$ \\
\hline Melon ** & Cuсumis melo $\mathrm{L}$. & Cucurbitaceae & $3-5$ & $\mathrm{Ag}$ & $\mathrm{Ag}, \mathrm{Mp}$ & $\mathrm{CA}, \mathrm{C}, \mathrm{W}, \mathrm{Z}$ & $\mathrm{CA}, \mathrm{C}, \mathrm{W}, \mathrm{Z}$ & $\mathrm{Ag}, \mathrm{Mp}, \mathrm{CA}, \mathrm{C}, \mathrm{W}, \mathrm{Z}$ \\
\hline Nigella & Nigella damascena L. & Ranunculaceae & 5 & $\varnothing$ & $\mathrm{ni}$ & $\mathrm{C}, \mathrm{W}, \mathrm{Z}$ & $\mathrm{ni}$ & $\underline{\mathrm{C}}, \underline{\mathrm{W}}, \underline{\mathrm{Z}}$ \\
\hline Pepper ** & Capsicum аппиит $\mathrm{L}$. & Solanaceae & $5-8$ & na & na & na & na & na \\
\hline Ryegrass & Lolium perenne $\mathrm{L}$. & Poaceae & $7-8$ & $\varnothing$ & $\mathrm{Mp}$ & $\varnothing$ & $\mathrm{ni}$ & $\mathrm{Mp}$ \\
\hline Sainfoin * & Onobrychis viciifolia Scop. & Leguminosae & $5-7$ & $\varnothing$ & $\varnothing$ & $\varnothing$ & $\mathrm{ni}$ & $\varnothing$ \\
\hline Salad burnet * & Sanguisorba minor Scop. & Rosaceae & $5-6$ & $\varnothing$ & $\varnothing$ & $\varnothing$ & $\mathrm{ni}$ & $\varnothing$ \\
\hline Sweet marjoram * & Origanum majorana $\mathrm{L}$. & Lamiaceae & 6-8 & $\varnothing$ & $\varnothing$ & $\mathrm{C}$ & $\mathrm{ni}$ & $\underline{\mathrm{C}}$ \\
\hline White campion & Silene latifolia Poir. & Caryophyllaceae & 6 & $\varnothing$ & $\mathrm{Mp}$ & $\mathrm{C}$ & $\mathrm{C}$ & $\mathrm{Mp}, \mathrm{C}$ \\
\hline
\end{tabular}

na $=$ not applicable

ni= no information available

${ }^{a}$ Plant species with an asterisk are included in the flower mix

Plant species with two asterisks are reference species:

Melon is reference species for Aphis gossypii and virus risk assessment

Pepper is reference species for Myzus persicae risk assessment

${ }^{\mathrm{b}}$ Plants with the same letters are not significantly different

${ }^{c}$ Aphid risks according to Blackman and Eastop 2006, Kavallieratos et al., 2007

$\mathrm{Ag}$ (Aphis gossypii)

Mp (Myzus persicae)

${ }^{\mathrm{d}}$ Virus risks according to:

CA (CABYV): Lecoq et al., 1992

C (CMV): Edwardson and Christie, 1997

W (WMV): Edwardson and Christie, 1991

Z (ZYMV): Desbiez and Lecoq, 1997

${ }^{\mathrm{e}}$ Underlined risks correspond to new descriptions compared to literature

$\varnothing=$ risk considered as negligible according biotests and/or literature 